\title{
PHYSICAL CAPACITY, RESPIRATORY AND PERIPHERAL MUSCLE STRENGTH IN HEART FAILURE
}

\author{
CAPACIDADE FISICA, FORÇA MUSCULAR RESPIRATÓRIA E PERIFÉRICA NA INSUFICIÊNCIA CARDÍACA
}

CAPACIDAD FÍSICA, FUERZA MUSCULAR RESPIRATORIA Y PERIFÉRICA EN INSUFICIENCIA CARDÍACA

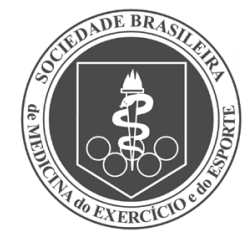

Original Article

Artigo OrIGINAL Artículo Original

\author{
Karla Luciana Magnani Seki' (DD \\ (Physiotherapist) \\ Ana Paula Lé Queirózz, \\ (Physiotherapist) \\ Ariele dos Santos Costa ${ }^{4}$ (D) \\ (Physiotherapist) \\ Daniele de Oliveira' (iD \\ (Physiotherapist) \\ Patrícia de Oliveira' (iD \\ (Physiotherapist) \\ Emmanuella Nunes da Costa 3 (D) \\ (Cardiologist) \\ Gustavo Christofoletti ${ }^{1,5}$ \\ (Physiotherapist)
}

\begin{abstract}
1. Universidade Federal de Mato Grosso do Sul (UFMS), Campo Grande, MS, Brazil.

2. Universidade Anhanguera (UNIDERP), Campo Grande, MS, Brazil.

3. Hospital Regional de Mato Grosso do Sul, MS, Brazil.

4. Universidade Federal de São Paulo (UNIFESP), São Paulo, SP, Brazil.

5. Masters and Doctorate Program in Health and Development in the Midwest Region (Programa de Mestrado e Doutorado em Saúde e Desenvolvimento na Região Centro-Oeste) (UFMS); Masters Program in Movement Science (Programa de Mestrado em Ciências do Movimento) delivered by the Instituto Integrado de Saúde (INISA/UFMS), MS, Brazil.
\end{abstract}

\section{Correspondence:}

Karla Luciana Magnani Seki. Universidade Federal de Mato Grosso do Sul, Cidade Universitária, Av. Costa e Silva - Pioneiros, Campo Grande, MS, Brazil. 79070-900 klmagnani@gmail.com

\begin{abstract}
Introduction: The Glittre-ADL test is a submaximal test that involves sitting/lifting, stair climbing/descending, and weight-bearing activities, with considerable potential for use in assessing exercise intolerance in heart failure. Objectives: To investigate the influence of heart failure on maximal physical (ergometric test - ET) and functional (6MWT and Glittre-ADL test) capacity, on respiratory (IPmax and EPmax) and peripheral (handgrip strength) muscle strength, and to study the correlation between the variables evaluated. Methods: A prospective comparative study that assessed 44 subjects divided into two groups: G1, with 26 heart patients (20 men/ 6 women, $65.26 \pm 8.50$ years), and $G 2$, with 18 healthy subjects paired with $G 1$ on the basis of sex ratio, age and anthropometric characteristics ( 10 men/8 women, $60.72 \pm 8.39$ years). The comparison of categorical variables was performed using the chi-square test, while continuous variables were compared using the Student $t$ test or Mann-Whitney test. The study of the correlation between variables was conducted using the Pearson coefficient for EPmax and handgrip strength, while the Spearman correlation coefficient was used for the others, with a statistical significance level of 5\%. Results: Groups were homogeneous in terms of sex ratio, age and anthropometric characteristics. G1 had a worse performance in all tests: ET ( $p=0.016)$, Glittre-ADL $(p=0.001), 6 \mathrm{MWT}(p=0.001), \operatorname{IPmax}(p=0.012), E P \max (p=0.007)$ and handgrip strength $(p=0.036)$. There was a negative correlation between the Glittre-ADL test and 6MWT, and the Glittre-ADL test and handgrip strength in G1. Conclusion: Heart failure resulted in impairment of maximal physical and functional capacity and of respiratory and peripheral muscle strength, with a negative correlation between functional capacity and handgrip strength. Level of evidence Il; Prospective comparative study.
\end{abstract}

Keywords: Heart failure; Respiratory function tests; Cardiorespiratory fitness.

\section{RESUMO}

Introdução: O teste AVD-Glittre é um teste submáximo que envolve atividades de sentar/levantar, subir/descer degraus e sustentação de pesos, que tem grande potencial de uso na avaliação da intolerância ao esforço na insuficiência cardíaca. Objetivos: Pesquisar a influência da insuficiência cardíaca na capacidade física máxima (teste ergométrico - TE) e funcional (TC6 e teste AVD-Glittre), na força dos músculos respiratórios ( $P I_{\text {máx }}$ ePE $E_{\text {máx }}$ ) e periféricos (força de preensão palmar) e estudar a correlação entre as variáveis avaliadas. Métodos: Estudo prospectivo comparativo que avaliou 44 individuos divididos em dois grupos: G1, com 26 cardiopatas (20 homens/ 6 mulheres, 65,26 8,50 anos) e G2 com 18 indivíduos saudáveis pareados com o G1 quanto à distribuição de sexo, idade e características antropométricas (10 homens/8 mulheres, 60,72 $\pm 8,39$ anos). A comparação das variáveis categóricas foi realizada pelo teste do qui-quadrado e a das variáveis contínuas, pelo teste t de Student ou Mann-Whitney. O estudo da correlação entre variáveis foi feito pelo índice de Pearson para $P E_{\text {máx }}$ e força de preensão palmar; para as demais, pelo índice de correlação de Spearman, com nível de significância estatístico de 5\%. Resultados: Os grupos foram homogêneos quanto à distribuição de sexo, idade e características antropométricas. O G1 apresentou pior desempenho em todos os testes: $\operatorname{TE}(p=0,016), \operatorname{AVD}-G l i t t r e(p=0,001), T C \sigma^{\prime}(p=0,001), P I_{\text {máx }}(p=0,012), P E_{\text {máx }}(p=0,007)$ e força de preensão palmar $(p=0,036)$. Houve correlação negativa entre AVD-Glittre e TC6 e AVD-Glittre e força de preensão palmar em G1. Conclusão: A insuficiência cardíaca resultou em comprometimento da capacidade física máxima, funcional e da força muscular respiratória e periférica, com correlação negativa entre capacidade funcional e força de preensão palmar. Nível de Evidência ll; Estudo Prospectivo e Comparativo.

Descritores: Insuficiência cardíaca; Testes de função respiratória; Aptidão cardiorrespiratória.

\section{RESUMEN}

Introducción: La prueba AVD-Glittre es una prueba submáxima que implica sentarse/pararse, subir/bajarescalones y actividades con carga de peso, que tiene un gran potencial para uso en la evaluación de la intolerancia al estrés en la insuficiencia cardíaca. Objetivos: Investigar la influencia de la insuficiencia cardíaca en la capacidad física máxima (prueba ergométrica-PE) y funcional (prueba 6MWTy AVD-Glittre), en la fuerza de los músculos respiratorios $\left(P I_{\text {máx }}\right.$ Y $P E_{\text {máx }}$ y periféricos (fuerza de agarre manual) y estudiar la correlación entre las variables evaluadas. Métodos: Estudio prospectivo comparativo que evaluó a 44 individuos, divididos en dos grupos: G1, con 26 cardíacos (20 hombres/6 mujeres, 65,26 $\pm 8,50$ años) y G2 con 18 individuos sanos emparejados con G1 con respecto a la distribución de sexo, edad y características antropométricas (10 hombres/8 mujeres, 60,72 $\pm 8,39$ años). La comparación de las variables 
categóricas se realizó utilizando la prueba de chi-cuadrado y la de variables continuas, utilizando la prueba t de Student o Mann-Whitney. El estudio de la correlación entre variables se realizó utilizando el índice de Pearson para $P E_{\text {máx }}$ y fuerza de agarre manual; para las demás, se utilizó el índice de correlación de Spearman, con un nivel de significación estadística del 5\%. Resultados: Los grupos fueron homogéneos en cuanto a la distribución por sexo, edad y características antropométricas. El G1 presentó el peor desempeño en todas las pruebas: $P E(p=0,016)$, AVD- Glittre $(p=0,001), 6 M W T(p=0,001), P I_{\text {máx }}(p=0,012), P E_{\text {máx }}(p=0,007)$ y fuerza de agarre manual $(p=0,036)$. Hubo una correlación negativa entre AVD-Glittre y 6MWT y AVD-Glittre y la fuerza de agarre manual en G1. Conclusión: La insuficiencia cardíaca resultó en un deterioro de la fuerza muscular máxima, funcional y respiratoria y periférica, con una correlación negativa entre la capacidad funcional y la fuerza de agarre manual. Nivel de Evidencia Il; Estudio

\section{Prospectivo y Comparativo.}

Descriptores: Insuficiencia cardíaca; Pruebas de función respiratoria; Capacidad cardiovascular.

\section{INTRODUCTION}

Exercise intolerance in heart failure (HF) is associated with central cardiovascular involvement and skeletal muscle changes. ${ }^{1}$ Such changes result from neurohormonal system modulation; exacerbation of the muscular sympathetic nervous system; renin-angiotensin-aldosterone system activation, ${ }^{2}$ oxidative stress, muscle apoptosis and immune system activation (release of cytokines). ${ }^{3}$ These adaptations also occur in the respiratory muscles and predispose HF patients to early-onset fatigue and dyspnea and limited physical capacity.

Cardiopulmonary exercise testing is the gold standard for defining exercise intolerance in HF. However, it involves high costs and requires specialized professionals. Thus, other submaximal tests have been applied and show a good correlation with maximal tests. ${ }^{4}$ The 6 -minute Walk Test (6MWT) is an example. However, the reproduction of Activities of Daily Living (ADL) is scaled down to the act of walking alone. In this manner, other tests that assess functional capacity in a more comprehensive way have been described. Such tests include the Glittre-ADL Test, which involves, in addition to walking, activities such as sitting and standing up, climbing and descending stairs, and arm movements with weight-bearing. This test was originally described in COPD patients. ${ }^{5}$ Although COPD and chronic heart failure are anatomically and pathologically distinct, exercise intolerance, dyspnea and fatigue are common alterations in these conditions. Abnormalities in structure, lung function and peripheral impairment occur in both. ${ }^{6}$ Changes in the ventilation/perfusion ratio with a consequent gas exchange deficit are present in both diseases, and in HF are caused by impaired cardiac pump function, increased left atrial pressure, and pulmonary congestion. ${ }^{7}$ Thus, the purpose of this study was to investigate the influence of stable chronic heart failure on maximal and functional physical capacity, on respiratory muscle strength, and on the correlation between the variables studied.

\section{MATERIALS AND METHODS}

An observational cross-sectional study, approved by the UFMS Institutional Review Board (37934714.7.0000.0021), in which 44 subjects of both sexes participated. The subjects signed an informed consent form and were divided into two groups: G1: 26 chronic heart disease patients (20 men and 6 women, mean age $65.26 \pm 8.50$ years) and $G 2$ : 18 healthy subjects paired with G1 on the basis of sex ratio, age and anthropometric characteristics ( 10 men and 8 women, with a mean age of $60.72 \pm 8.39$ years). G1 participants were recruited from the Cardiac Rehabilitation Clinic of the Hospital Regional de Mato Grosso do Sul, with NYHA HF functional classification (FC) I, II and III, stages B and C, and hemodynamically stable. $\mathrm{G} 2$ was composed of volunteers recruited from the academic institution and community.
The study included individuals with clinical conditions that could not be exacerbated by physical exertion, without medical contraindication to exercise, and without cognitive deficit, hypertrophic cardiomyopathy, unstable angina, dyspnea at rest, acute myocardial infarction and/or cardiac surgery performed less than six months previously, lung diseases, or limitations that would interfere with mobility. Each study participant was assessed at four time points (on alternate days), with a random order in the application of the tests: 1- pulmonary function assessment and anthropometric assessment; 2- ergometric test; 3Glittre-ADL test and 4- 6MWT.

The following data were verified in the anthropometric assessment: weight using Welmy ${ }^{R}$ mechanical scale for adults (São Paulo/SP/Brazil), height: aluminum $2.00 \mathrm{~m}$ scale ruler for anthropometric measures according to the Rocha ${ }^{8}$ method, BMI (weight in kilograms/height ${ }^{2}$ in meters $^{8}$ ), and waist-hip ratio. ${ }^{9}$

Ergometric tests were carried out by a cardiologist, in a laboratory with controlled temperature and relative humidity.$^{10}$ The ramp-adapted Bruce protocol was applied in both groups. 12-lead electrocardiogram (ECG) findings were recorded at rest, obtained in the supine position and in three modified leads, CM5, aVF and V2, in the orthostatic position and during the test, using the computerized system Ergo-PC 13 for Windows and a Micromed Centurion 300 treadmill (São Paulo/SP/ Brazil). The estimated indirect measurement of maximal oxygen uptake (VO2max) in METs was calculated using the Foster formula with handrail support, with VO2: $0.69 \times$ VO2 (ACSM) + 3.330, where ACSM stands for the American College of Sports Medicine formula. ${ }^{11}$

The 6MWT was conducted in a flat corridor measuring 30 meters in length according to ATS recommendations. ${ }^{12}$ The parameters of normality for the distance covered in the 6MWT were determined using the equations proposed by Iwama et al. ${ }^{13}$ Two tests were performed at least 30 min apart, and in the case of a difference greater than 10\% between distances, a third test was performed.

The Glittre-ADL test was carried out as recommended by Skumlien et al. ${ }^{5}$ To summarize, we clocked the time spent to cover five laps of a circuit, during which time the study participants carried a rucksack on their backs (2.5 kg for women and $5 \mathrm{~kg}$ for men), walked, climbed and descended steps, and moved $1 \mathrm{Kg}$ objects on a rack with shelves. The time spent was compared with the time predicted using the equation proposed for the Brazilian population. ${ }^{14}$ Two tests were performed with a 30-minute interval, and in the case of a difference greater than 10\% between distances, a third test was performed.

Respiratory muscle strength was obtained by measuring maximum respiratory pressures with the use of the MVD300 manometer (Globalmed. Porto Alegre/RS/Brazil). The method and the normality references used were those proposed by Neder et al. ${ }^{15}$ 


\section{Peripheral muscle strength}

Peripheral muscle strength was assessed by measuring handgrip strength, using the Saehan ${ }^{R}$ dynamometer (Saehan Corp. MASAN, Korea). The method used was that described by the American Association of Hand Therapists (FESS), ${ }^{16}$ and the reference values by age and sex were consistent with those established by Bohannon and Schaubert. ${ }^{17}$

\section{Statistical analysis}

SPSS 20.0 software was used. The Chi-squared test was used for categorical variables and the Student's t-test or Mann-Whitney test to compare the continuous variables. Either Pearson's coefficient or Spearman's correlation coefficient was used to analyze the correlation between the variables studied. The level of statistical significance used was $p<0.05$.

\section{RESULTS}

The anthropometric characteristics of the sample are described in Table 1, which shows that the groups were homogeneous in terms of sex ratio, age, and anthropometric characteristics.

The clinical characteristics of G1 are listed in Table 2, which shows that functional class I and stage $C$ were more frequent. The mean LVEF of G1 was $35.00 \pm 14.97 \%$. Regarding the etiology of chronic heart failure, we observed a predominance of ischemic cardiomyopathy, followed by dilated cardiomyopathy.

The results of the tests that evaluated maximal physical capacity and functional capacity are described in Table 3 . In all tests, the majority of $\mathrm{G} 1$ was classified as having a reduced result, while in $\mathrm{G} 2$, the majority was considered normal, with a significant difference for all 3 tests: ET $(p=0.016)$, Glittre-ADL $(p=0.001)$ and 6MWT $(p=0.001)$.

In G2, nine volunteers did not undergo the ET and two did not undergo the Glittre-ADL test as they were unable to get time off work.

Table 1. Anthropometric characteristics of the two groups studied.

\begin{tabular}{c|c|c|c|c}
\hline Parameters & $\mathbf{G 1}$ & $\mathbf{G 2}$ & Statistical test & $\mathbf{P}$ \\
\hline Sex & $\mathbf{n}(\%)$ & $\mathbf{n}(\%)$ & Chi-squared & \\
\hline Female & $6(23.07 \%)$ & $8(44.44 \%)$ & \multirow{2}{*}{2.24} & \multirow{2}{*}{0.135} \\
\hline Male & $20(76.92 \%)$ & $10(55.50 \%)$ & & \\
\hline Age & & & T test & \\
\hline & $65.26 \pm 8.50^{*}$ & $60.72 \pm 8.39^{*}$ & 1.75 & 0.087 \\
\hline BMl & & & T test & \\
\hline & $29.96 \pm 5.28^{*}$ & $28.04 \pm 4.91^{*}$ & 1.22 & 0.227 \\
\hline W/HR & & & Mann Whitney & \\
\hline & $0.96 \pm 0.11 \dagger$ & $0.93 \pm 0.12 \dagger$ & 176.50 & 0.169 \\
\hline
\end{tabular}

Table 2. Clinical characteristics of the HF patients studied (G1).

\begin{tabular}{|c|c|c|}
\hline & n (LVEF\%) & (\%) \\
\hline \multicolumn{3}{|c|}{ Functional class } \\
\hline 1 & $12(39,17 \pm 9,81)^{*}$ & 46,15 \\
\hline$\|$ & $10(34,70 \pm 11,15)^{*}$ & 38.46 \\
\hline III & $04(26,66 \pm 8,52)^{*}$ & 15,38 \\
\hline \multicolumn{3}{|c|}{ Stage } \\
\hline B & 3 & 11,53 \\
\hline $\mathrm{C}$ & 23 & 88,46 \\
\hline \multicolumn{3}{|c|}{ Disease etiology } \\
\hline Ischemic cardiomyopathy & 13 & 50.00 \\
\hline LV dilated cardiomyopathy & 07 & 26.92 \\
\hline Alcoholic cardiomyopathy & 03 & 11.5 \\
\hline Chagasic dilated cardiomyopathy & 03 & 11.53 \\
\hline
\end{tabular}

Of the seven volunteers who underwent the ET, only $14.2 \%$ showed a reduction and $85.7 \%$ had normal results in the test. In G1, one patient did not complete the 6MWT due to an orthopedic restriction. Thus, 24 patients completed the 6MWT.

The results in terms of the respiratory muscle strength and handgrip variables of both groups studied are described in Table 4, which shows that the majority of $\mathrm{G} 1$ participants had a reduction in IPmax ( $p=0.012)$, $\operatorname{EPmax}(p=0.007)$ and dynamometry $(p=0.036)$, with a statistically significant difference in comparison to $\mathrm{G} 2$.

The study of the correlation between the variables studied in $\mathrm{G} 1$ is represented in Table 5. A significant negative correlation was observed between the Glittre-ADL and 6MWT tests, and the Glittre-ADL test and handgrip strength. There was also a significant positive correlation between the ET and 6MWT.

Table 3. Statistical analysis of the following tests: ergometric, Glittre-ADL and Six-minute walk test in the two groups studied.

\begin{tabular}{|c|c|c|c|c|}
\hline Tests conducted & G1 & G2 & $\begin{array}{l}\text { Statistical } \\
\text { test }\end{array}$ & $p$ \\
\hline ET & & & Chi-squared & \multirow{3}{*}{0.016} \\
\hline Normal & $n=10(38.46 \%)$ & $\mathrm{n}=9(81.81 \%)$ & \multirow{2}{*}{5.81} & \\
\hline Reduced & $n=16(61.53 \%)$ & $n=2(18.18 \%)$ & & \\
\hline GLITTRE-ADL & & & Chi-squared & \multirow{3}{*}{0.001} \\
\hline Normal & $n=5(19.23 \%)$ & $n=12(75.00 \%)$ & \multirow{2}{*}{12.78} & \\
\hline Reduced & $n=21(80.76 \%)$ & $n=4(25.00 \%)$ & & \\
\hline Time spent on Glittre-ADL & & & $\begin{array}{c}\text { Mann } \\
\text { Whitney }\end{array}$ & \multirow{3}{*}{0.001} \\
\hline Median & 3.33 & 2.47 & \multirow{2}{*}{77.0} & \\
\hline Interquartile & 1.34 & 0.88 & & \\
\hline 6MWT & & & Chi-squared & \multirow{3}{*}{0.001} \\
\hline Normal & $n=4(16 \%)$ & $n=13(72.22 \%)$ & \multirow{2}{*}{13.838} & \\
\hline Reduced & $\mathrm{n}=21(84 \%)$ & $n=5(27.77 \%)$ & & \\
\hline
\end{tabular}

ET - ergonomic test; $n=$ number of individuals; Glittre-ADL: Glittre's Activity of Daily Living Test; 6 MWT - six-minute walk test.

Table 4. Statistical analysis of respiratory muscle strength and peripheral muscle strength of the two groups studied.

\begin{tabular}{|c|c|c|c|c|}
\hline Variables & G1 & G2 & Statistical test & $p$ \\
\hline \multicolumn{3}{|c|}{ IPmax } & \multicolumn{2}{|c|}{ Chi-squared } \\
\hline Normal & 05 (29.23\%) & $10(55.25 \%)$ & \multirow{2}{*}{6.24} & \multirow{2}{*}{0.012} \\
\hline Reduced & $21(80.76 \%)$ & 08 (44.44\%) & & \\
\hline \multicolumn{5}{|c|}{ EPmax } \\
\hline Normal & 08 (30.76\%) & $13(72.22 \%)$ & \multirow{2}{*}{7.32} & \multirow{2}{*}{0.007} \\
\hline Reduced & 18 (69.23\%) & $05(27.77 \%)$ & & \\
\hline \multicolumn{5}{|c|}{ Dynamometry } \\
\hline Normal & 12 (46.15\%) & $14(77.77 \%)$ & \multirow{2}{*}{4.40} & \multirow{2}{*}{0.036} \\
\hline Reduced & $14(53.84 \%)$ & 04 (22.22\%) & & \\
\hline
\end{tabular}

IPmax-Maximum inspiratory pressure; EPmax-Maximum expiratory pressure; 6MWT- six-minute walk test; ET-ergometric test.

Table 5. Statistical analysis of the correlation between variables studied in the HF group (G1).

\begin{tabular}{c|c|c|c|c|c|c}
\hline & IPmax & EPmax & 6MWT & $\begin{array}{c}\text { Glittre- } \\
\text { ADL }\end{array}$ & ET & $\begin{array}{c}\text { Handgrip } \\
\text { strength }\end{array}$ \\
\hline IPmax & 1.00 & & & & & \\
\hline EPmax & 0.183 & 1.00 & & & & \\
\hline 6MWT & 0.259 & 0.278 & 1.00 & & & \\
\hline Glittre-ADL & -0.348 & -0.057 & $-0.484^{*}$ & 1.00 & & \\
\hline ET & -0.092 & 0.024 & $0.409^{*}$ & -0.108 & 1.00 & \\
\hline Handgrip strength & 0.270 & 0.153 & 0.274 & $-0.607^{*}$ & -0.044 & 1.00 \\
\hline
\end{tabular}

*Significant correlations ( $\mathrm{p}<0.05)$; IPmax- maximum inspiratory pressure; EPmax- maximum expiratory pressure: 6MWT - six-minute walk test; Glittre-ADL test - Glittre's activities of daily living test; ET- ergometric test. 


\section{DISCUSSION}

Individuals with stable chronic heart failure investigated in this particular study showed impairment of maximal physical capacity, functional capacity and respiratory and peripheral muscle strength, in comparison to the group of healthy individuals studied. This reinforces the negative influence of peripheral and respiratory muscle impairment characteristic of heart failure on the performance of activities of daily living and on maximal physical capacity. ${ }^{18}$ Histological, metabolic and functional changes in skeletal muscle, including respiratory musculature, due to $\mathrm{HF}$, result in early-onset fatigue and dyspnea and consequent limitation of functional capacity. Maximum inspiratory pressure is related to HF severity and ventilatory limitation during exercise, in addition to being a prognostic indicator of $\mathrm{HF}^{19}$

Studies report a reduction in peripheral and respiratory muscle strength in HF patients. ${ }^{20,21}$ Such functional changes in the inspiratory musculature may result in exacerbation of the metaboloreflex induced by the work of the inspiratory musculature and the exaggerated increase in ventilation mediated by the chemoreflex during exercise. ${ }^{22}$ The assessment of activities of daily living can be performed by direct observation, by applying questionnaires or scales that are inexpensive and user-friendly, yet subjective and less accurate, or by applying submaximal tests, such as: the 6MWT, Glittre-ADL test and Shuttle Walk Test (SWT). ${ }^{23}$

The cardiopulmonary exercise test has established a reputation as the reference standard for the objective measurement of functional capacity and stratification of heart failure patient prognosis. However, this is a high-cost technique that requires sophisticated equipment and specialized manpower, and is only found in certain centers; in addition, it requires greater patient collaboration. ${ }^{4}$ Due to the widespread availability, safety, and ease of execution of the $6 \mathrm{MWT}$, this test is increasingly being used as an alternative to the CPT to assess the functional capacity of HF patients. This test has proven useful and reliable in assessing the functional capacity, prognosis and therapeutic efficacy of patients with this syndrome. ${ }^{24}$ However, it is worth mentioning that, through the 6MWT, $\mathrm{ADL}$ capacities are restricted to the act of walking.

In order to represent ADLs in a more realistic manner, new scientific instruments have been proposed. In 2006, the Glittre-ADL test was developed by Skumlien et al..$^{5}$ to assess the limitation in ADL of COPD patients. Although COPD and chronic heart failure are anatomically and pathologically distinct, exercise intolerance, dyspnea and fatigue are common alterations in these conditions. ${ }^{6}$

The main advantages of the Glittre-ADL test are that it requires little space, is easy to apply, and simulates activities besides walking, such as climbing and descending stairs, sitting down and getting up from a chair, and the performance of weight-bearing movements with the upper limbs and trunk flexion. This inclusion of activities that use both upper and lower limbs reflects the limitations of activities of daily living more accurately than the 6MWT. ${ }^{25}$ These advantages make the Glittre-ADL an assessment tool with excellent clinical viability prospects for individuals with heart failure. ${ }^{26}$

The Glittre-ADL test has already proven to be a user-friendly, valid and reliable tool for measuring functional status in patients with COPD;5,26,27 applicable in the assessment of limitation in activities of daily living (ADL) in subjects with heart failure, class III and IV; ${ }^{23}$ and able to distinguish between the functional status of healthy individuals and those with COPD. ${ }^{25}$ It has also shown a relationship with sitting and walking time in patients with COPD, and a physiological response similar to the 6MWT, with a slight increase in oxygen consumption. ${ }^{27}$
Regarding the use of the Glittre-ADL test in patients with HF, to date, only three national studies ${ }^{23,28,29}$ and no international studies have been found.

Valadares et al. ${ }^{23}$ conducted a study to verify the applicability of the London Chest Activity of Daily Living (LCADL) scale and the Glittre-ADL test (GlittreT) in the assessment of the functional limitation of individuals with functional class III and IV HF. Ten patients with HF (57 \pm 9 years; $27.5 \pm 4.5 \mathrm{~kg} / \mathrm{m}^{2}$ ) of both sexes, with functional class III and IV and left ventricular ejection fraction (LVEF) $34 \pm 7 \%$ participated in the study. As regards results, the authors describe a positive correlation between the score of the total LCADL scale and time of the Glittre-ADL test, and state that the Glittre-ADL test was negatively correlated with the 6MWT, LVEF and functional capacity category of the SF-36 questionnaire.

Chiodelli et al. ${ }^{28}$ studied the relationship between respiratory and peripheral muscle strength and functional limitation in nine patients with heart failure (age $53.5 \pm 6$ years, NYHA functional class II and III and LVEF $26.2 \pm$ $8.1 \%)$. As regards results, the authors reported that the HF patients studied had reduced inspiratory, expiratory and lower limb muscle strength. However, the time spent on the Glittre-ADL test showed a strong correlation only with quadriceps muscle strength. Chiodelli et al. ${ }^{28}$ also observed a strong negative correlation ( $r=-0.81$ ) between the Glittre-ADL test and the 6MWT.

Fernandes-Andrade et al. ${ }^{29}$ investigated whether the Glittre Test is able to discriminate the functional status of patients with cardiovascular diseases. Forty-two individuals (62.21 \pm 12.07 years) were assessed using the Glittre-ADL and SWT tests, the Human Activity Profile (HAP) and the Duke Activity Status Index (DASI). The execution time of the Glittre-ADL test was compared with the different ranges of the SWT, HAP and DASI tertiles. The authors report a statistically significant difference in the execution time of the Glittre-ADL test between the tertiles of the SWT ( $p=0.0001)$, between the tertiles of the three tests studied, thus demonstrating that the Glittre-ADL test is able to distinguish between functional classes of individuals with CVD, especially in relation to individuals with greater functional impairment.

It is noteworthy that the national studies by Valadares et al. ${ }^{23}$ and Chiodelli et al. ${ }^{28}$ reported a negative correlation between the time spent on the Glittre-ADL test and the 6MWT, and that the study by Fernandes-Andrade et al. ${ }^{29}$ also showed that the Glittre-ADL test is able to recognize differences in the functional capacity of patients with cardiovascular diseases. These results are consistent with our findings from this particular study. Therefore, we can suggest that the Glittre-ADL test really is an instrument with considerable potential for use to assess functional capacity in HF patients.

\section{CONCLUSIONS}

In the sample studied, heart failure resulted in impaired maximal and functional physical capacity and impaired respiratory and peripheral muscle strength, with a significant negative correlation between functional capacity and handgrip strength.

\section{ACKNOWLEDGMENTS}

This work was carried out with the support of the Coordenação de Aperfeiçoamento de Pessoal de Nível Superior - Brazil (CAPES - Coordination for the Improvement of Higher Education) - Funding Code 001.

All authors declare no potential conflict of interest related to this article 


\section{REFERENCES}

1. Ventura-Clapier R, Garnier A, VekslerV. Energy metabolism in heart failure. J Physiol. 2004;555(Pt 1):1-13.

2. Swedberg K. Review Importance of neuroendocrine activation in chronic heart failure. Impact on treatment strategies. Eur J Heart Failure. 2000;2(3):229-33.

3. Steele IC, Nugent AM, Maguire S, Hoper M, Campbell G, Halliday MI, et al. Cytokine profile in chronic cardiac failure. European Journal of Clinical Investigation. 1996;26(11):1018-22.

4. Zugck C, Krüger C, Dürr S, Gerber SH, Haunstetter A, Hornig K, et al. Is the 6-minute walk test a reliable substitute for peak oxygen uptake in patients with dilated cardiomyopathy? Eur Heart J. 2000;21(7):540-9.

5. Skumlien S, Hagelund T, Bjørtuft O, Ryg MS. A field test of functional status as performance of activities of daily living in COPD patients. Respir Med. 2006;100(2):316-23.

6. Muthumala A. Chronic heart failure and chronic obstructive pulmonary disease: one problem, one solution? Int J Cardiol. 2008;125(1):1-3.

7. Grazzini M, Stendardi L, Gigliotti F, Scano G. Pathophysiology of exercise dyspnea in healthy subjects and in patients with chronic obstrutive pulmonary disease (COPD). Respir Med. 2005;99(11):1403-12.

8. Rocha PE. Medidas e avaliação em ciências do esporte. $2^{\text {a }}$ ed. Rio de Janeiro: Sprint, 1997.

9. Carneiro G, Faria AN, Ribeiro Filho FF, Guimarães A, Lerário D, Ferreira SR, et al. Influência da distribuição da gordura corporal sobre a prevalência de hipertensão arterial e outros fatores de risco cardiovascular em indivíduos obesos. Rev Assoc Med Bras (1992). 2003;49(3):306-11.

10. Il Diretrizes da Sociedade Brasileira de Cardiologia sobre teste ergométrico. Arq Bras Cardiol. 2002;78(Suppl 2):1-17.

11. Maneghelo RS, Araújo CG, Stein R, Mastrocolla LE, Albuquerque PF, Serra SM. III Diretrizes da Sociedade Brasileira de Cardiologia sobre teste ergométrico. Arq Bras Cardiol. 2010;95(5 Suppl 1):1-26.

12. ATS Statement: Guidelines for the six minute walk tests. ATS Committee on Proficiency Standards for Clinical Pulmonary Function Laboratories. Am J Respir Crit Care Med. 2002;166(1):111-7.

13. Iwama AM, Andrade GN, Shima P, Tanni SE, Godoy I, Dourado VZ. The six-minute walk test and body weight-walk distance product in healthy Brazilian subjects. Braz J Med Biol Res. 2009;42(11):1080-5.

14. Reis CM. Equação de referência para o teste de AVD Glittre. 2014. Dissertação [Mestrado]. Florianópolis: Universidade do Estado de Santa Catarina (UDESC); 2014.

15. Neder JA, Andreoni S, Castelo-Filho A, Nery LE. Reference values for lung function tests. I. Static volumes. Braz J Med Biol Res. 1999;32(6):703-17.
16. Fess, EE. Grip strength. In: Casanova JS. Clinical Assessment Recommendations. 2nd ed. Chicago: American Society of Hand Therapists; 1992. p. 41-5.

17. Bohannon RW, Schaubert KL. Test-retest reliability of grip-strength measures obtained over a 12-week interval from community-dwelling elders. J Hand Ther 2005;18(4):426-7.

18. Gosker HR, Wouters EF, van der Vusse GJ, Schols AM. Skeletal muscle dysfunction in chronic obstructive pulmonary disease and chronic heart failure: underlying mechanisms and therapy perspectives. Am J Clin Nutr. 2000;71(5):1033-47.

19. St Croix CM, Morgan BJ, Wetter TJ, Dempsey JA. Fatiguing inspiratory muscle work causes reflex sympathetic activation in humans. J Physiol. 2000;529 (Pt 2):493-504

20. Montemezzo D, Fregonezi GA, Pereira DA, Britto RR, Reid WD. Arch Phys Med Rehabil. 2014;95(7):1398-407.

21. Bosnak-Guclu M, Arikan H, Savci S, Inal-Ince D, Tulumen E, Aytemir K, et al. Effects of inspiratory muscle training in patients with heart failure. Respir Med. 2011;105(11):1671-81.

22. Chiappa GR, Roseguini BT, Vieira PJ, Alves CN, Tavares A, Winkelmann ER, et al. Inspiratory muscle training improves blood flow to resting and exercising limbs in patients with chronic heart failure. J Am Coll Cardiol. 2008;51(17):1663-71.

23. Valadares YD, Corrêa KS, Silva BO, Araujo CL, Karloh M, Mayer AF. Aplicabilidade de testes de atividades de vida diária em indivíduos com insuficiência cardíaca. Rev Bras Med Esporte. 2011;17(5):310-14.

24. Rubim VS, Drumond Neto C, Romeo JL, Montera MW. Valor prognóstico do teste de caminhada de seis minutos na insuficiência cardíaca. Arq Bras Cardiol. 2006;86(2):120-5.

25. Correa KS, Karloh M, Martins LQ, Santos K, Mayer AF. Can the Glittre ADL test differentiate the functional capacity of COPD patients from that of healthy subjects? Rev Bras Fisioter. 2011;15(6):467-73.

26. Lage SM, Britto RR, Baião EA, Ribeiro AL, Rocha MO, Beloti FR, et al. Perfil de atividade humana e capacidade funcional em indivíduos com insuficiência cardíaca crônica. Rev Bras Fisioter. 2008;12(Suppl):39.

27. Karloh M, Karsten M, Pissaia FV, de Araujo CL, Mayer AF. Physiological responses to the Glittre-ADL test in patients with chronic obstructive pulmonary disease. J Rehabil Med. 2014;46(1):88-94.

28. Chiodelli GC, Araujo CL, Reis CM, Fonseca FR, Karloh M, Mayer, AF. Relação das Forças Musculares Respiratória e Periférica com a Limitação Funcional em Pacientes Com Insuficiência Cardíaca. Rev Bras Ci Mov. 2015;23(1):136-45.

29. Fernandes-Andrade, AA, Britto, RR, Soares, DC, Velloso M, Pereira, DA. Evaluation of the Glittre-ADL test as an instrument for classifying functional capacity of individuals with cardiovascular diseases. Braz J Physical Therapy 2017;21(5):321-8. 